\title{
LEVEL II SCOUR ANALYSIS FOR BRIDGE 42 (BRIDTH00040042) on TOWN HIGHWAY 4, crossing DAILEY HOLLOW BROOK, BRIDGEWATER, VERMONT
}

U.S. Geological Survey Open-File Report 96-243

Prepared in cooperation with

VERMONT AGENCY OF TRANSPORTATION and

FEDERAL HIGHWAY ADMINISTRATION 


\section{LEVEL II SCOUR ANALYSIS FOR BRIDGE 42 (BRIDTH00040042) on TOWN HIGHWAY 4, crossing DAILEY HOLLOW BROOK, BRIDGEWATER, VERMONT}

By SCOTT A. OLSON and MATTHEW A. WEBER

U.S. Geological Survey Open-File Report 96-243

Prepared in cooperation with

VERMONT AGENCY OF TRANSPORTATION and

FEDERAL HIGHWAY ADMINISTRATION 


\title{
U.S. DEPARTMENT OF THE INTERIOR BRUCE BABBITT, Secretary
}

\author{
U.S. GEOLOGICAL SURVEY \\ Gordon P. Eaton, Director
}

For additional information write to:

District Chief

U.S. Geological Survey 361 Commerce Way

Pembroke, NH 03275
Copies of this report may be purchased from:

U.S. Geological Survey Earth Science Information Center Open-File Reports Section Box 25286, MS 517 Federal Center

Denver, CO 80225 


\section{CONTENTS}

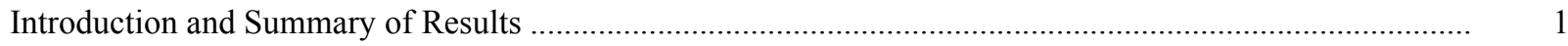

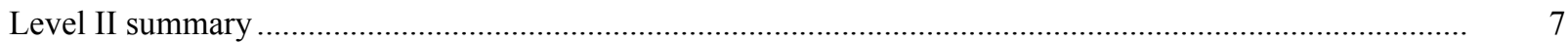

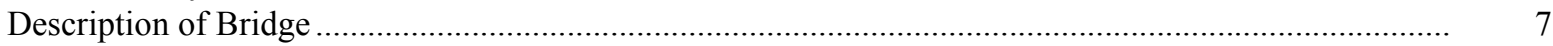

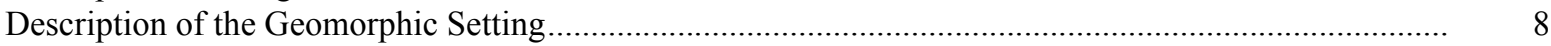

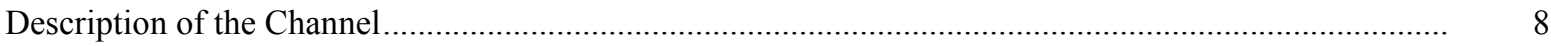

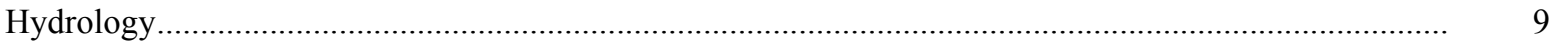

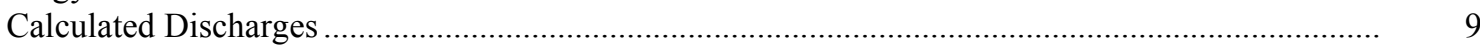

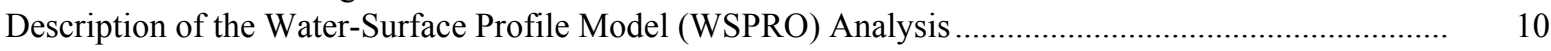

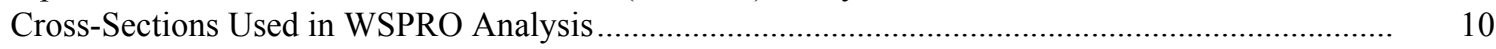

Data and Assumptions Used in WSPRO Model ...................................................................... 11

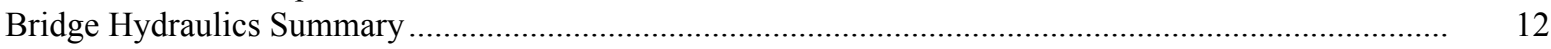

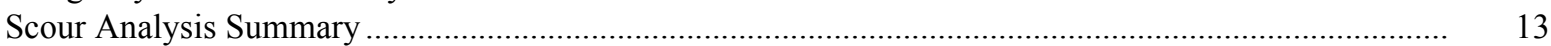

Special Conditions or Assumptions Made in Scour Analysis ...................................................... 13

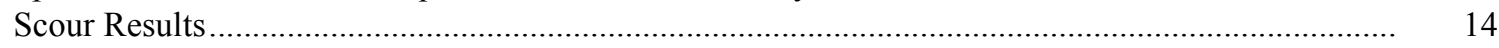

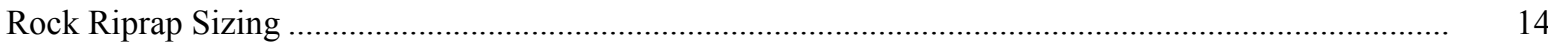

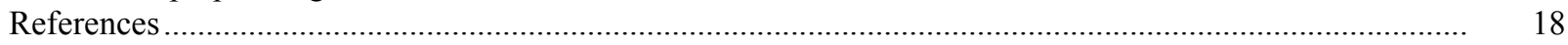

Appendixes:

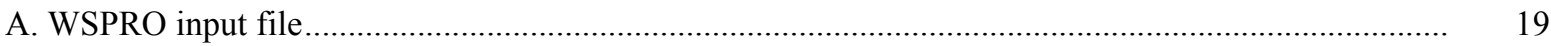

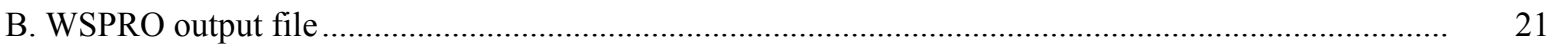

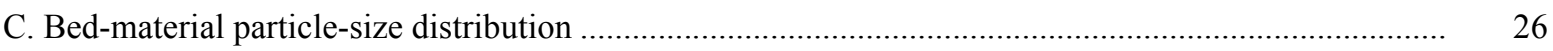

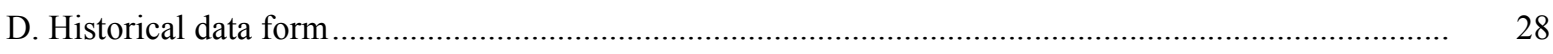

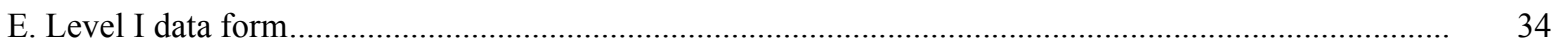

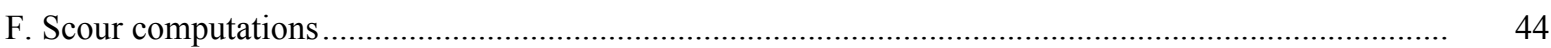

\section{FIGURES}

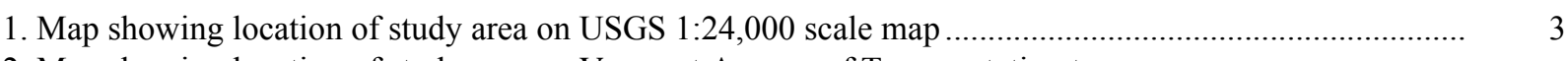

2. Map showing location of study area on Vermont Agency of Transportation town

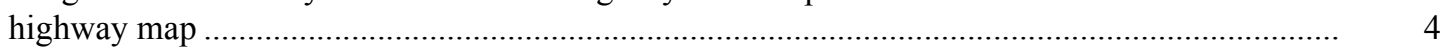

3. Structure BRIDTH00040042 viewed from upstream (November 1, 1994).............................................. 5

4. Downstream channel viewed from structure BRIDTH00040042 (November 1, 1994).......................... 5

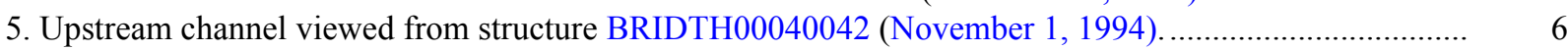

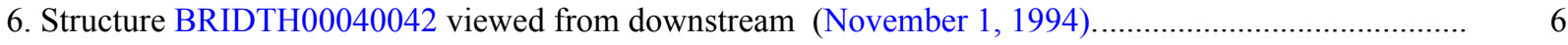

7. Water-surface profiles for the 100- and 500-year discharges at structure BRIDTH00040042 on Town Highway 4, crossing Dailey Hollow Brook,

Bridgewater, Vermont.

8. Scour elevations for the 100- and 500-year discharges at structure BRIDTH00040042 on Town Highway 4, crossing Dailey Hollow Brook,

Bridgewater, Vermont.

\section{TABLES}

1. Remaining footing/pile depth at abutments for the 100-year discharge at structure BRIDTH00040042 on Town Highway 4, crossing Dailey Hollow Brook,

Bridgewater, Vermont

2. Remaining footing/pile depth at abutments for the 500-year discharge at structure

BRIDTH00040042 on Town Highway 4, crossing Dailey Hollow Brook,

Bridgewater, Vermont.

(

5

5

6

.




\begin{tabular}{|c|c|c|}
\hline Multiply & By & To obtain \\
\hline \multicolumn{3}{|c|}{ Length } \\
\hline inch (in.) & 25.4 & millimeter (mm) \\
\hline foot $(\mathrm{ft})$ & 0.3048 & meter $(\mathrm{m})$ \\
\hline mile (mi) & 1.609 & kilometer (km) \\
\hline \multicolumn{3}{|c|}{ Slope } \\
\hline foot per mile ( $\mathrm{ft} / \mathrm{mi})$ & 0.1894 & meter per kilometer $(\mathrm{m} / \mathrm{km})$ \\
\hline \multicolumn{3}{|c|}{ Area } \\
\hline square mile $\left(\mathrm{mi}^{2}\right)$ & 2.590 & square kilometer $\left(\mathrm{km}^{2}\right)$ \\
\hline \multicolumn{3}{|c|}{ Volume } \\
\hline cubic foot $\left(\mathrm{ft}^{3}\right)$ & $\begin{array}{l}0.02832 \\
\text { Velocity and Flow }\end{array}$ & cubic meter $\left(\mathrm{m}^{3}\right)$ \\
\hline foot per second (ft/s) & 0.3048 & meter per second $(\mathrm{m} / \mathrm{s})$ \\
\hline cubic foot per second $\left(\mathrm{ft}^{3} / \mathrm{s}\right)$ & 0.02832 & cubic meter per second $\left(\mathrm{m}^{3} / \mathrm{s}\right)$ \\
\hline $\begin{array}{l}\text { cubic foot per second per } \\
\text { square mile } \\
{\left[\left(\mathrm{ft}^{3} / \mathrm{s}\right) / \mathrm{mi}^{2}\right]}\end{array}$ & 0.01093 & $\begin{array}{l}\text { cubic meter per } \\
\text { second per square } \\
\text { kilometer }\left[\left(\mathrm{m}^{3} / \mathrm{s}\right) / \mathrm{km}^{2}\right]\end{array}$ \\
\hline
\end{tabular}

OTHER ABBREVIATIONS

$\begin{array}{lrlr}\mathrm{BF} & \text { bank full } & \text { LWW } & \text { left wingwall } \\ \mathrm{cfs} & \text { cubic feet per second } & \text { MC } & \text { main channel } \\ \mathrm{D}_{50} & \text { median diameter of bed material } & \text { RAB } & \text { right abutment } \\ \mathrm{DS} & \text { downstream } & \text { RABUT } & \text { face of right abutment } \\ \mathrm{elev} & \text { elevation } & \text { RB } & \text { right bank } \\ \mathrm{f} / \mathrm{p} & \text { flood plain } & \text { ROB } & \text { right overbank } \\ \mathrm{ft} & \text { square feet } & \text { RWW } & \text { right wingwall } \\ \mathrm{ft} / \mathrm{ft} & \text { feet per foot } & \text { TH } & \text { town highway } \\ \mathrm{JCT} & \text { junction } & \text { UB } & \text { under bridge } \\ \mathrm{LAB} & \text { left abutment } & \text { US } & \text { upstream } \\ \mathrm{LABUT} & \text { face of left abutment } & \text { USGS } & \text { United States Geological Survey } \\ \text { LB } & \text { left bank } & \text { VTAOT Vermont Agency of Transportation } \\ \text { LOB } & \text { left overbank } & \text { WSPRO } & \text { water-surface profile model }\end{array}$

In this report, the words "right" and "left" refer to directions that would be reported by an observer facing downstream. Sea level: In this report, "sea level" refers to the National Geodetic Vertical Datum of 1929-- a geodetic datum derived from a general adjustment of the first-order level nets of the United States and Canada, formerly called Sea Level Datum of 1929.

In the appendices, the above abbreviations may be combined. For example, USLB would represent upstream left bank. 


\title{
LEVEL II SCOUR ANALYSIS FOR BRIDGE 42 (BRIDTH00040042) ON TOWN HIGHWAY 4, CROSSING DAILEY HOLLOW BROOK, BRIDGEWATER, VERMONT
}

\author{
By Scott A. Olson and Matthew A. Weber
}

\section{INTRODUCTION AND SUMMARY OF RESULTS}

This report provides the results of a detailed Level II analysis of scour potential at structure BRIDTH00040042 on town highway 4 crossing Dailey Hollow Brook, Bridgewater, Vermont (figures 1-8). A Level II study is a basic engineering analysis of the site, including a quantitative analysis of stream stability and scour (U.S. Department of Transportation, 1993). A Level I study is included in Appendix E of this report. A Level I study provides a qualitative geomorphic characterization of the study site. Information on the bridge available from VTAOT files was compiled prior to conducting Level I and Level II analyses and can be found in Appendix D.

The site is in the Green Mountain physiographic division of central Vermont in the town of Bridgewater. The $2.20-\mathrm{mi}^{2}$ drainage area is in a predominantly rural and forested basin. In the vicinity of the study site, the overbanks are covered by shrubs and trees except for the upstream right overbank where there is a house. Dailey Hollow Brook enters Dailey Hollow Branch at the downstream face of the bridge.

In the study area, Dailey Hollow Brook has an incised, sinuous channel with a slope of approximately $0.035 \mathrm{ft} / \mathrm{ft}$. The channel top width and channel depth upstream of the bridge is $19 \mathrm{ft}$ and $3 \mathrm{ft}$, respectively. Downstream of the bridge and the confluence the channel top width and channel depth is $39 \mathrm{ft}$ and $2 \mathrm{ft}$ respectively. The predominant channel bed material is cobble and gravel $\left(\mathrm{D}_{50}\right.$ is $64.7 \mathrm{~mm}$ or $\left.0.212 \mathrm{ft}\right)$. The geomorphic assessment at the time of the Level I and Level II site visit on November 1, 1994, indicated that the reach was stable.

The town highway 4 crossing of Dailey Hollow Brook is a 25 -ft-long, one-lane bridge consisting of one 23-foot concrete span (Vermont Agency of Transportation, written communication, August 25,1994). The bridge is supported by vertical, concrete abutments with wingwalls. Type- 2 stone fill (less than 36 inches) exists along all four wingwalls, the downstream right road approach, and the channel banks in the immediate vicinity of the bridge. The channel is skewed approximately 20 degrees to the opening; the opening-skewto-roadway is also 20 degrees. Additional details describing conditions at the site are included in the Level II Summary and Appendices D and E. 
Scour depths and rock rip-rap sizes were computed using the general guidelines described in Hydraulic Engineering Circular 18 (Richardson and others, 1993). Total scour at a highway crossing is comprised of three components: 1) long-term streambed degradation; 2) contraction scour (due to accelerated flow caused by a reduction in flow area at a bridge) and; 3) local scour (caused by accelerated flow around piers and abutments). Total scour is the sum of the three components. Equations are available to compute depths for contraction and local scour and a summary of the results of these computations follows.

Contraction scour for modelled flows was $0.0 \mathrm{ft}$. Abutment scour ranged from 3.9 to $5.4 \mathrm{ft}$. with the worst-case abutment scour occurring at the 500-year discharge. Additional information on scour depths and depths to armoring are included in the section titled "Scour Results". Scoured-streambed elevations, based on the calculated scour depths, are presented in tables 1 and 2. A cross-section of the scour computed at the bridge is presented in figure 8. Scour depths were calculated assuming an infinite depth of erosive material and a homogeneous particle-size distribution.

It is generally accepted that the Froehlich equation (abutment scour) gives "excessively conservative estimates of scour depths" (Richardson and others, 1993, p. 48). Many factors, including historical performance during flood events, the geomorphic assessment, scour protection measures, and the results of the hydraulic analyses, must be considered to properly assess the validity of abutment scour results. Therefore, scour depths adopted by VTAOT may differ from the computed values documented herein, based on the consideration of additional contributing factors and experienced engineering judgement. 


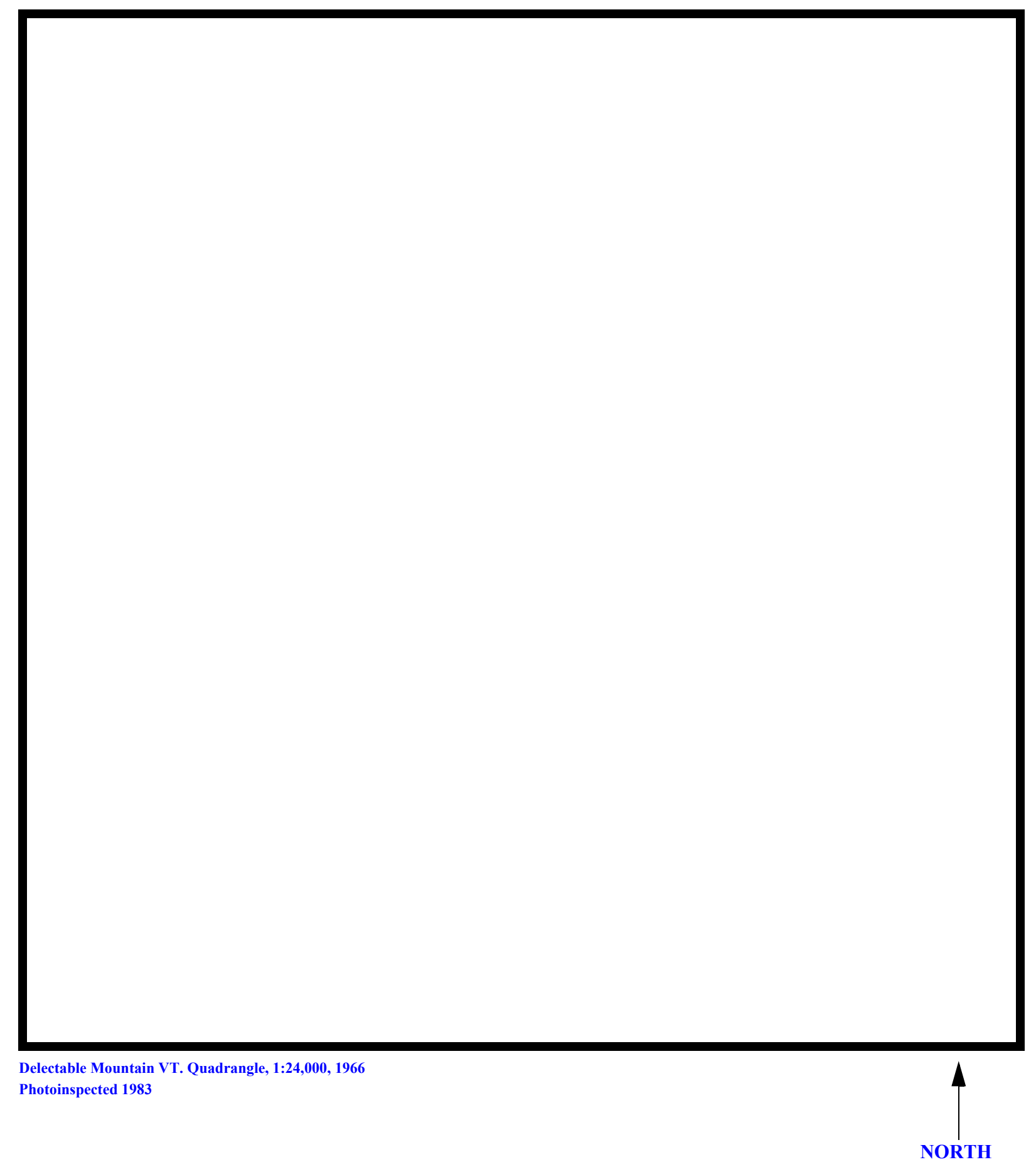

Figure 1. Location of study area on USGS 1:24,000 scale map. 
Figure 2. Location of study area on Vermont Agency of Transportation town highway map. 

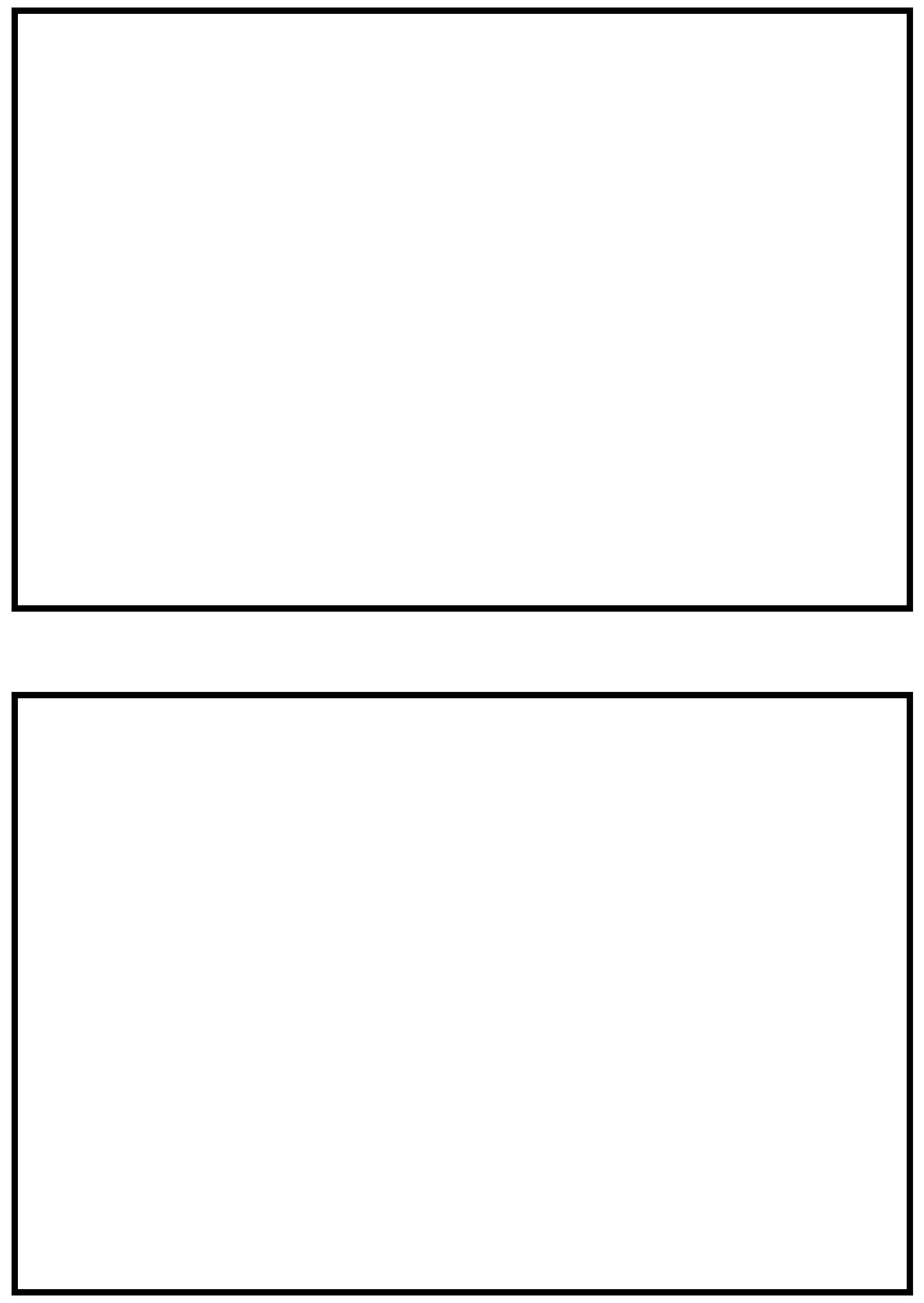

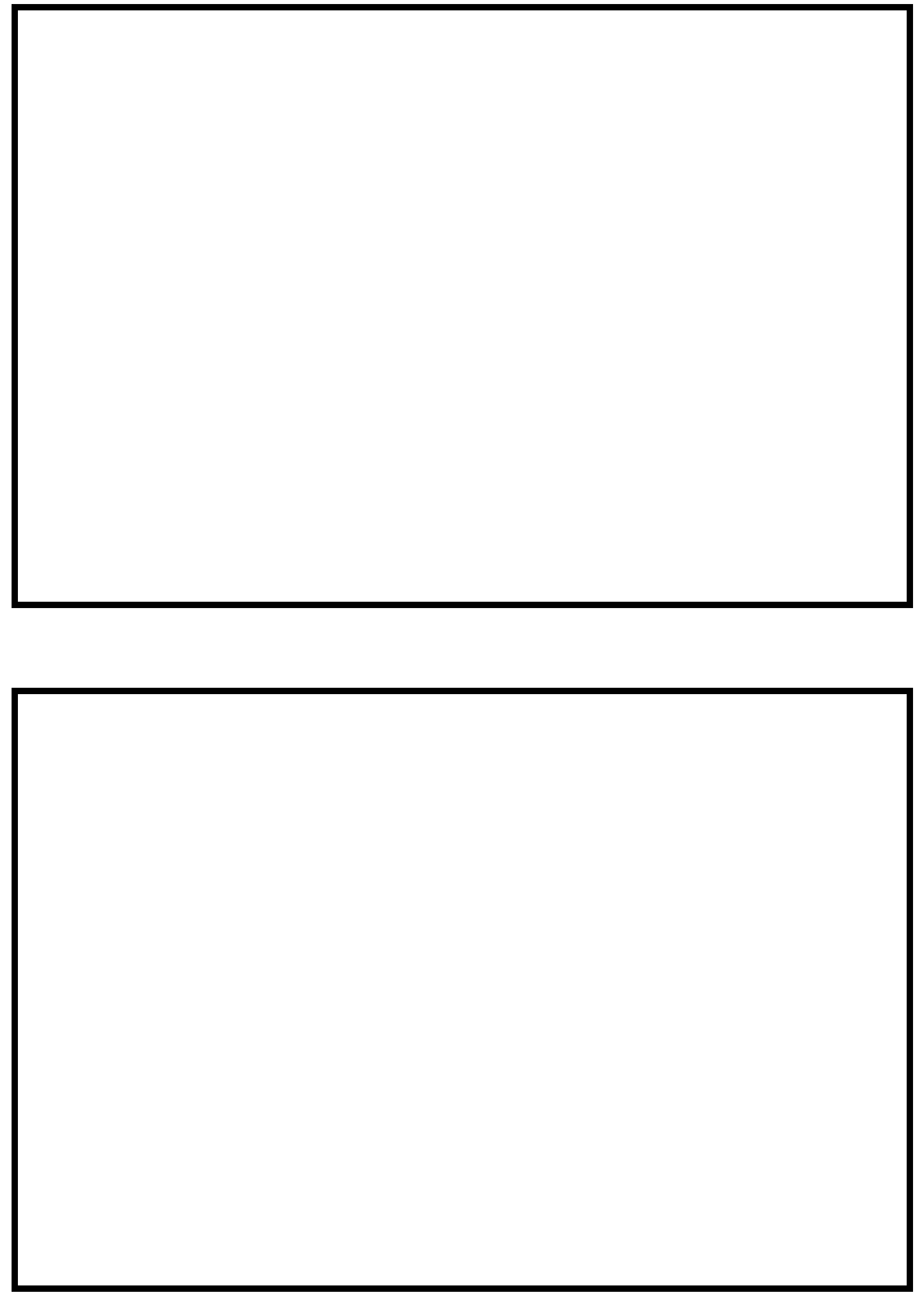


\section{LEVEL II SUMMARY}

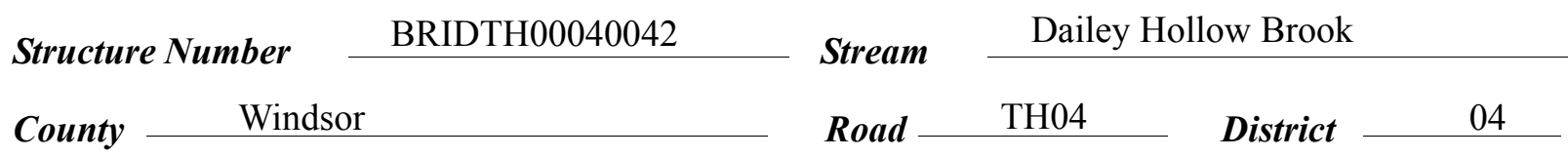

\section{Description of Bridge}

Bridge length $\frac{25}{2 t} \quad$ Bridge width $\frac{17.4}{f t}$ Max span length $\stackrel{23}{f t}$ Alignment of bridge to road (on curve or straight) vertical Abutment type

Stone fill on abutment? straight

Type-2 stone protects the wingwalls and the channel banks in the vicinity of the bridge. The downstream right road embankment is also protected with type- 2 stone. The abutments and wingwalls are concrete.

$$
\text { Y }
$$

$\underline{\mathrm{Y}} \quad \underline{\mathrm{Y}}$

Is bridge skewed to flood flow according to ' survey?

Angle

There is a mild bend in the channel approach. Since the opening skew to roadway matches the skew of 20 degrees, the left abutment is impacted only slightly by flow.

Debris accumulation on bridge at time of Level I or Level II site visit:

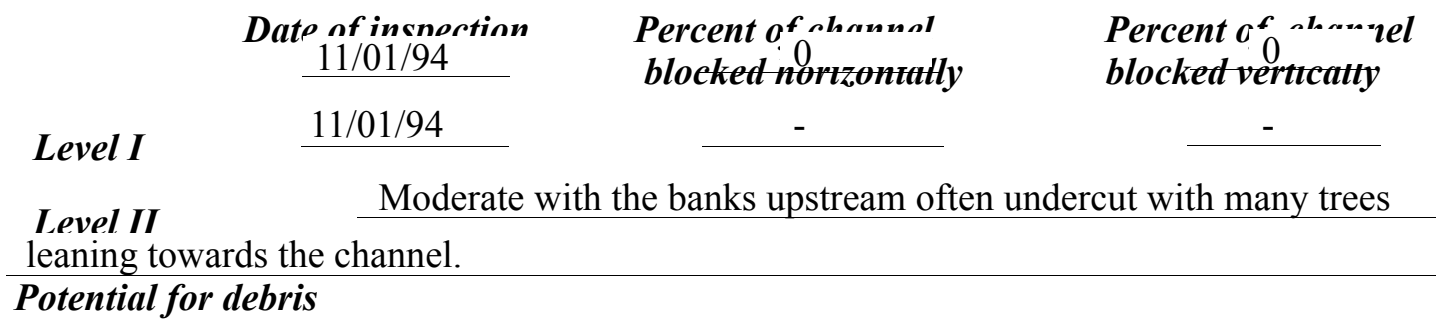

November 1, 1994. Dailey Hollow Brook empties into Dailey Hollow Branch immediately

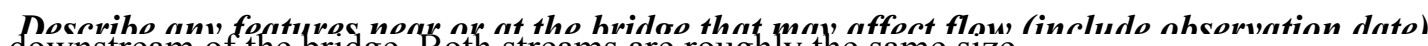
downstream of the bridge. Both streams are roughly the same size. 


\section{Description of the Geomorphic Setting}

General topography The bridge is in a steep narrow valley with moderate relief.

Geomorphic conditions at bridge site: downstream (DS), upstream (US)

Date of inspection $\quad 11 / 01 / 94$

DS left: $\quad$ Steep high bank. A gravel road parallels the left bank.

DS right: $\quad$ Moderately sloping bank.

US left: $\quad$ Steep high bank. A gravel road parallels the left bank.

US right: $\quad$ High river bank with a flat narrow overbank to a steep valley wall.

\section{Description of the Channel}

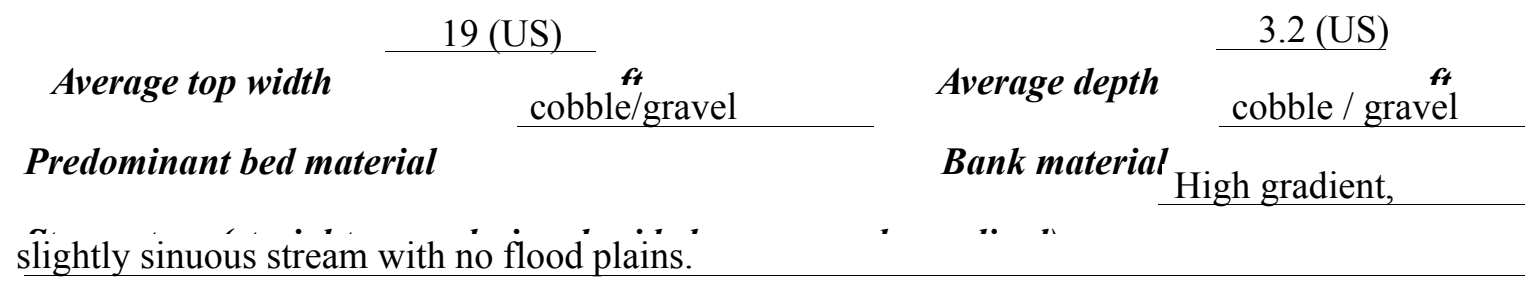

$11 / 01 / 94$

Vegetative co ${ }^{1}$ Forested.

DS left: $\quad$ Immediate banks have significant woody vegetation; grass on overbanks.

DS right: $\quad$ Forested.

US left: $\quad$ Immediate bank is grass; forested beyond.

US right: $\quad \underline{\mathrm{Y}}$

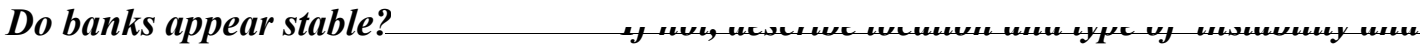

date of observation.

11/01/94--None.

Describe any obstructions in channel and date of observation. 


\title{
Hydrology
}

Drainage area $\quad 2.20 \quad \mathrm{mi}^{2}$

Percentage of drainage area in physiographic provinces: (approximate)

Physiographic province

Green Mountain Prov.
Percent of drainage area

100

\begin{abstract}
Is drainage area considered rural or urban?
Rural None.

urbanization:-
\end{abstract}

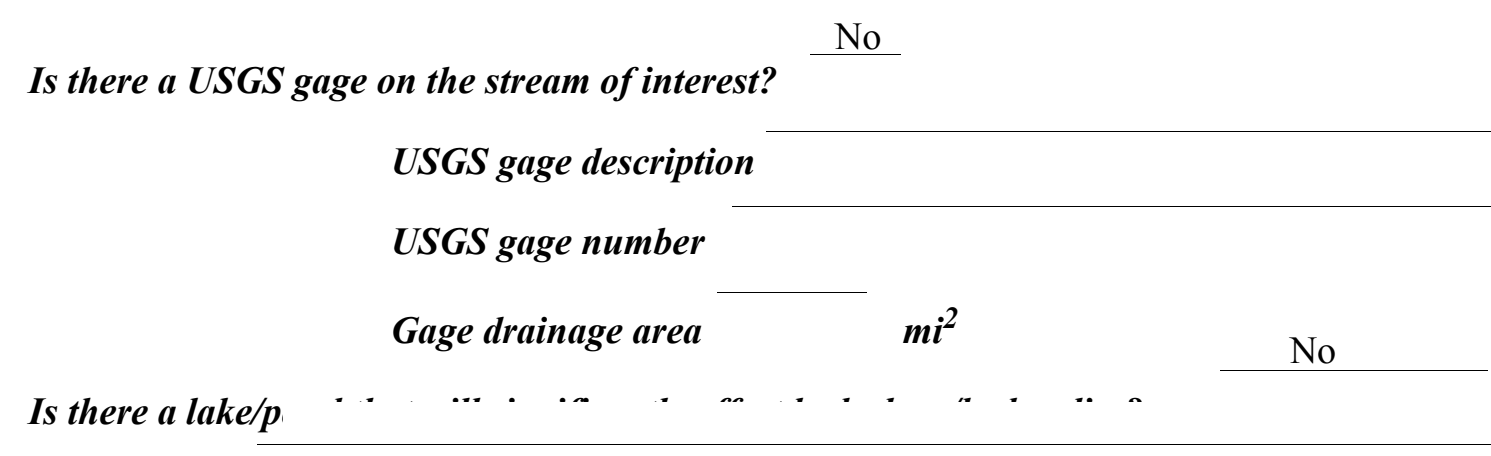

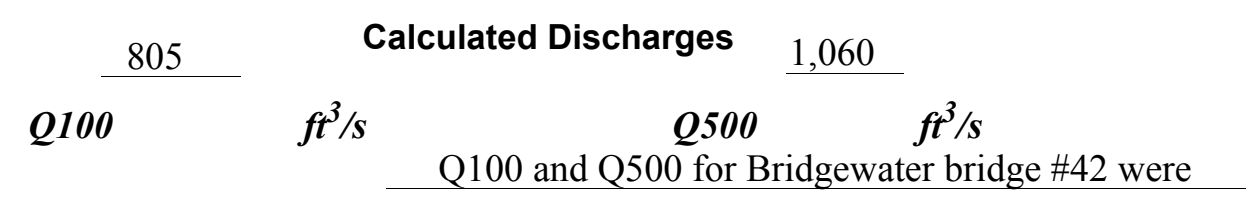

based on a drainage area relationship with Bridgewater bridge \#30 which is on Dailey Hollow Branch. The Q100 for bridge \#30 was taken from VTAOT files. The Q500 for bridge \#30 was determined by a weighted average of numerous extrapolated empirical methods which were applicable to a stream with it's size drainage in this region(Potter, 1957a\&b; Johnson and Tasker, 1974; FHWA, 1983; Talbot, 1887; FEMA, 1980). 


\section{Description of the Water-Surface Profile Model (WSPRO) Analysis}

Datum for WSPRO analysis (USGS survey, sea level, VTAOT plans)

USGS survey

Datum tie between USGS survey and VTAOT plans

Add 1355 feet to the study's

arbitrary datum to obtain VTAOT plans' datum (NAD27).

Description of reference marks used to determine USGS datum. $\quad$ RM1 is the center of a

bronze disk on top of the downstream end of the right abutment (elev. $99.62 \mathrm{ft}$, arbitrary survey

datum). RM2 is a chiseled $\mathrm{X}$ on the upstream end of the left abutment (elev. $99.23 \mathrm{ft}$, arbitrary

survey datum).

Cross-Sections Used in WSPRO Analysis

\begin{tabular}{|c|c|c|c|}
\hline${ }^{1}$ Cross-section & $\begin{array}{c}\text { Section } \\
\text { Reference } \\
\text { Distance } \\
\text { (SRD) in feet }\end{array}$ & $\begin{array}{l}{ }^{2} \text { Cross-section } \\
\text { development }\end{array}$ & Comments \\
\hline EXITX & -45 & 1 & $\begin{array}{l}\text { Surveyed exit section } \\
\text { downstream of the conflu- } \\
\text { ence of a Dailey Hollow } \\
\text { Brook and Dailey Hollow } \\
\text { Branch (this section mod- } \\
\text { elled with the combined } \\
\text { discharge). }\end{array}$ \\
\hline EXIT2 & -20 & 2 & $\begin{array}{l}\text { Exit section (templated } \\
\text { from EXITX) }\end{array}$ \\
\hline FULLV & 0 & 2 & $\begin{array}{l}\text { Downstream Full-valley } \\
\text { section (Templated from } \\
\text { EXITX) }\end{array}$ \\
\hline BRIDG & 0 & 1 & Bridge section \\
\hline RDWAY & 9 & 1 & Road Grade section \\
\hline APPRO & 55 & 1 & Approach section \\
\hline
\end{tabular}

${ }^{1}$ For location of cross-sections see plan-view sketch included with Level I field form, Appendix E.

For more detail on how cross-sections were developed see WSPRO input file. 


\section{Data and Assumptions Used in WSPRO Model}

Hydraulic analyses of the reach were done by use of the Federal Highway Administration's WSPRO step-backwater computer program (Shearman and others, 1986, and Shearman, 1990). The analysis reported herein reflects conditions existing at the site at the time of the study. Furthermore, in the development of the model it was necessary to assume no accumulation of debris or ice at the site. Results of the hydraulic model are presented in the Bridge Hydraulic Summary, Appendix B, and figure 7.

Channel roughness factors (Manning's "n") used in the hydraulic model were estimated using field inspections at each cross section following the general guidelines described by Arcement, Jr. and Schneider (1989). Final adjustments to the values were made during the modelling of the reach. Channel " $n$ " values for the reach ranged from 0.055 to 0.075 , and overbank " $n$ " values ranged from 0.055 to 0.105 .

Since the confluence of Dailey Hollow Brook and Dailey Hollow Branch was at the immediate downstream face of the bridge, the exit section (EXITX) was surveyed just downstream of the confluence. Normal depth at the exit section (EXITX) was assumed and used as the starting water surface for the model. This depth was computed by use of the slopeconveyance method outlined in the User's manual for WSPRO (Shearman, 1990). The slope used was $0.0221 \mathrm{ft} / \mathrm{ft}$ which was determined from surveyed thalweg points downstream of the confluence.

The discharges used in the normal depth computations were $1,780 \mathrm{ft}^{3} / \mathrm{s}$ (100-year) and 2,260 $\mathrm{ft}^{3} / \mathrm{s}$ (500-year), which are the estimated combined flow of the Dailey Hollow Brook and Dailey Hollow Branch. Both streams are assumed to peak at the same time since each has similar basin characteristics including drainage area. The 100-year discharge of Dailey Hollow Branch is from the VTAOT database (written communication, May 1995). The 500-year discharge for Dailey Hollow Branch was based on a drainage area relationship (2.2/2.5) with the study site.

The surveyed exit section was then used as a template and moved upstream in the model with a correction for the bed slope to a location one bridge length downstream of the bridge and the discharge was changed to only include the flows of Dailey Hollow Brook. 


\section{Bridge Hydraulics Summary}

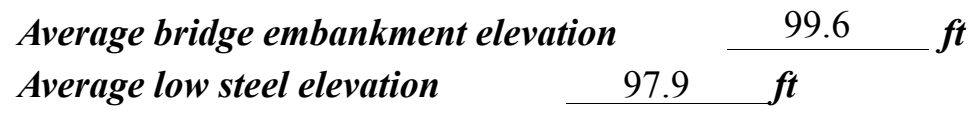

100-year discharge $\quad 805 \quad \mathrm{ft}^{3} / \mathrm{s}$

Water-surface elevation in bridge opening $\quad 90.7 \quad f t$

Road overtopping? ___ N Discharge over road ___ _ , is

Area of flow in bridge opening $\quad 106 \quad \mathrm{ft}^{2}$

Average velocity in bridge opening $\quad \begin{array}{lll}7.6 & \mathrm{ft} / \mathrm{s}\end{array}$

Maximum WSPRO tube velocity at bridge $\quad 9.5 \mathrm{ft} / \mathrm{s}$

Water-surface elevation at Approach section with bridge 91.6

Water-surface elevation at Approach section without bridge $\quad 91.8$

Amount of backwater caused by bridge $\quad \ldots \quad-{ }_{-} \quad$ it

500-year discharge $\quad 1,060 \quad \mathrm{ft}^{3} / \mathrm{s}$

Water-surface elevation in bridge opening

$91.5 f t$

Road overtopping? ___ N Discharge over road $-{ }^{-}, \mathrm{s} / \mathrm{s}$

Area of flow in bridge opening $\quad 121 \quad \mathrm{ft}^{2}$

Average velocity in bridge opening $\quad 8.8 \mathrm{ft} / \mathrm{s}$

Maximum WSPRO tube velocity at bridge $11.1_{\text {_ }}$ 's

Water-surface elevation at Approach section with bridge

92.6

Water-surface elevation at Approach section without bridge

Amount of backwater caused by bridge

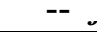

Incipient overtopping discharge ___ -- $f^{3} / \mathrm{s}$

Water-surface elevation in bridge opening $\quad--\quad t$

Area of flow in bridge opening _ -- $\mathrm{ft}^{2}$

Average velocity in bridge opening $\quad--\quad f t / s$

Maximum WSPRO tube velocity at bridge $\quad--\quad f t / s$

Water-surface elevation at Approach section with bridge

Water-surface elevation at Approach section without bridge

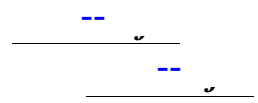

Amount of backwater caused by bridge _ 


\section{Scour Analysis Summary}

\section{Special Conditions or Assumptions Made in Scour Analysis}

Scour depths were computed using the general guidelines described in Hydraulic Engineering Circular 18 (Richardson and others, 1993). Scour depths were calculated assuming an infinite depth of erosive material and a homogeneous particle-size distribution. The results of the scour analysis are presented in tables 1 and 2 and a graph of the scour depths is presented in figure 8.

Contraction scour was computed by use of the live-bed contraction scour equation (Richardson and others, 1993, p. 33, equation 16,17). For contraction scour computations, the average depth in the contracted section (AREA/TOPWIDTH) is subtracted from the depth of flow computed by the scour equation (Y2) to determine the actual amount of scour.

Abutment scour was computed by use of the Froehlich equation (Richardson and others, 1993, p. 49, equation 24). Variables for the Froehlich equation include the Froude number of the flow approaching the embankments, the length of the embankment blocking flow, and the depth of flow approaching the embankment less any roadway overtopping. 


\section{Scour Results}

$$
\text { 100-yr discharge 500-yr discharge }
$$

(Scour depths in feet)

Main channel

Live-bed scour

Clear-water scour

Depth to armoring

Left overbank

Right overbank

Local scour:

Abutment scour

Left abutment

Right abutment

Pier scour

Pier 1

Pier 2

Pier 3
4.3

3.9-
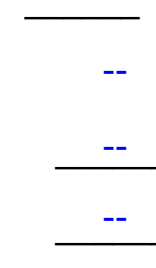

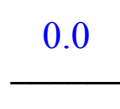

$2.3^{-}$
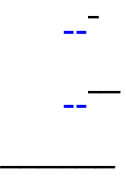
discharge 


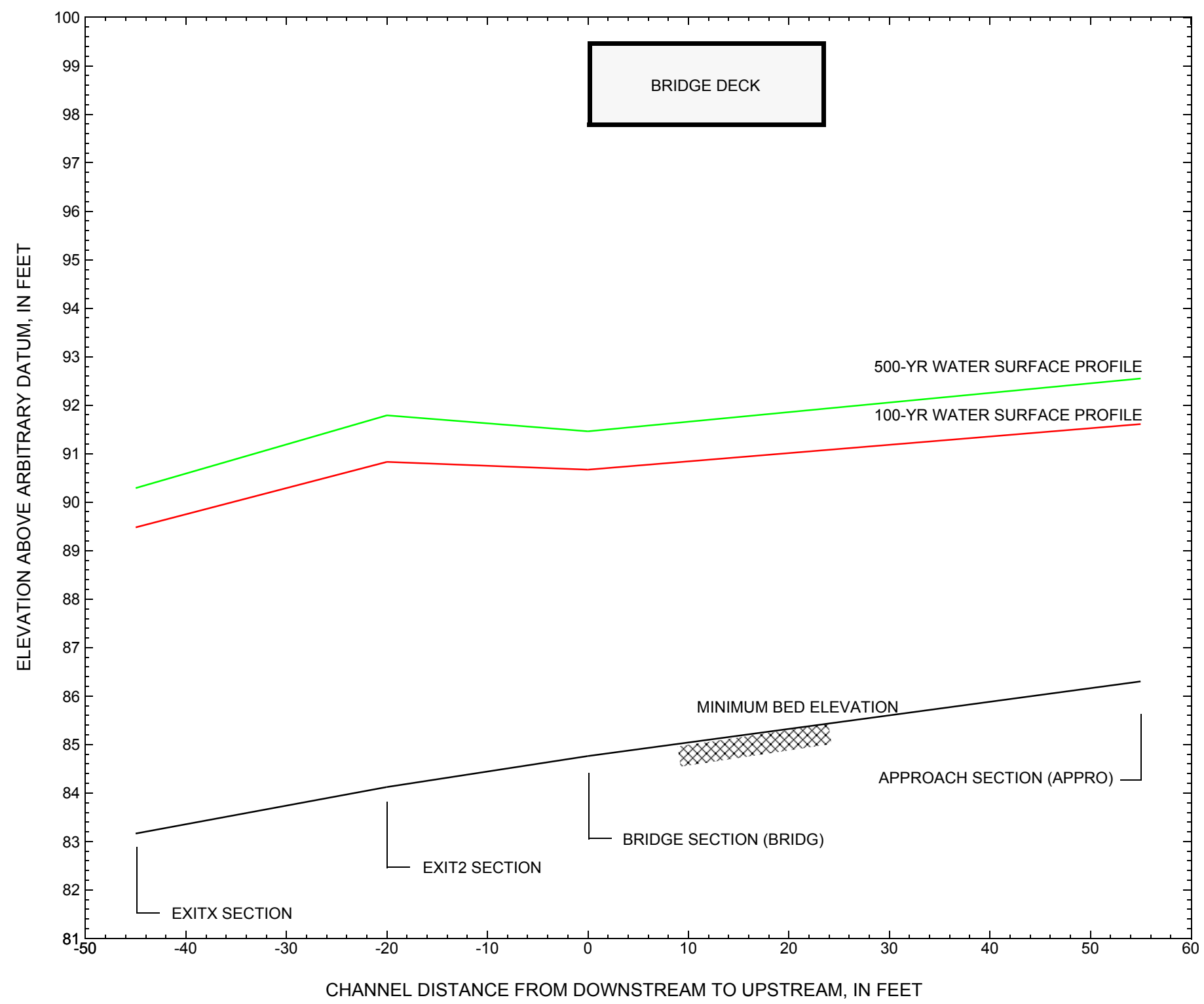

Figure 7. Water-surface profiles for the 100- and 500-yr discharges at structure BRIDTH00040042 on town highway 4, crossing Dailey Hollow Brook, Bridgewater, Vermont. 


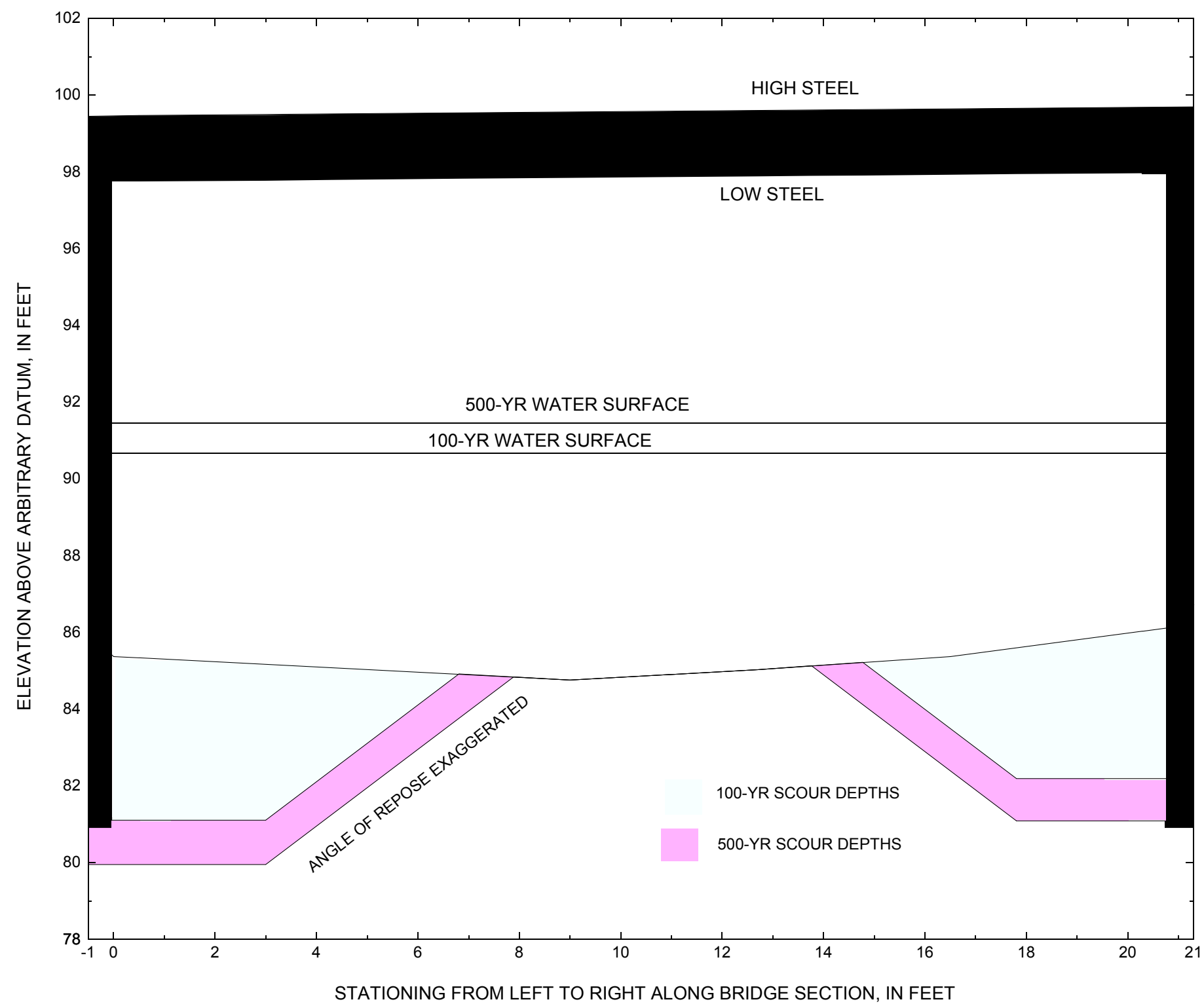

Figure 8. Scour elevations for the 100-yr and 500-yr discharges at structure BRIDTH00040042 on town highway 4, crossing Dailey Hollow Brook, Bridgewater, Vermont. 
Table 1. Remaining footing/pile depth at abutments for the 100-year discharge at structure BRIDTH00040042 on Town Highway 4, crossing Dailey Hollow Brook, Bridgewater, Vermont.

[VTAOT, Vermont Agency of Transportation; --,no data]

\begin{tabular}{|c|c|c|c|c|c|c|c|c|c|c|c|}
\hline Description & Station $^{1}$ & $\begin{array}{l}\text { VTAOT } \\
\text { plans' } \\
\text { bridge seat } \\
\text { elevation } \\
\text { (feet) }\end{array}$ & $\begin{array}{c}\text { Surveyed } \\
\text { minimum } \\
\text { low-chord } \\
\text { elevation }{ }^{2} \\
\text { (feet) }\end{array}$ & $\begin{array}{c}\text { Bottom of } \\
\text { footing } \\
\text { elevation } \\
\text { (feet) }\end{array}$ & $\begin{array}{c}\text { Channel } \\
\text { elevation at } \\
\text { abutment/ } \\
\text { pier }^{2} \\
\text { (feet) }\end{array}$ & $\begin{array}{l}\text { Contraction } \\
\text { scour depth } \\
\text { (feet) }\end{array}$ & $\begin{array}{l}\text { Abutment } \\
\text { scour } \\
\text { depth } \\
\text { (feet) }\end{array}$ & $\begin{array}{l}\text { Pier } \\
\text { scour } \\
\text { depth } \\
\text { (feet) }\end{array}$ & $\begin{array}{l}\text { Depth of } \\
\text { total scour } \\
\text { (feet) }\end{array}$ & $\begin{array}{c}\text { Elevation of } \\
\text { scour }^{2} \\
\text { (feet) }\end{array}$ & $\begin{array}{c}\text { Remaining } \\
\text { footing/pile } \\
\text { depth } \\
\text { (feet) }\end{array}$ \\
\hline \multicolumn{12}{|c|}{100 -yr. discharge is 1,780 cubic-feet per second } \\
\hline Left abutment & 0.0 & 1452.4 & 97.66 & 81 & 85.4 & 0.0 & 4.3 & -- & 4.3 & 81.1 & 0 \\
\hline Right abutment & 20.8 & 1452.8 & 98.13 & 81 & 86.1 & 0.0 & 3.9 & -- & 3.9 & 82.2 & 1 \\
\hline
\end{tabular}

${ }^{1}$. Measured along the face of the most constricting side of the bridge.

2. Arbitrary datum for this study.

Table 2. Remaining footing/pile depth at abutments for the 500-year discharge at structure BRIDTH00040042 on Town Highway 4, crossing Dailey Hollow Brook, Bridgewater, Vermont.

[VTAOT, Vermont Agency of Transportation; --, no data]

\begin{tabular}{|c|c|c|c|c|c|c|c|c|c|c|c|}
\hline Description & Station $^{1}$ & $\begin{array}{c}\text { VTAOT } \\
\text { plans' } \\
\text { bridge seat } \\
\text { elevation } \\
\text { (feet) }\end{array}$ & $\begin{array}{l}\text { Surveyed } \\
\text { minimum } \\
\text { low-chord } \\
\text { elevation }{ }^{2} \\
\text { (feet) }\end{array}$ & $\begin{array}{l}\text { Bottom of } \\
\text { footing } \\
\text { elevation } \\
\text { (feet) }\end{array}$ & $\begin{array}{c}\text { Channel } \\
\text { elevation at } \\
\text { abutment/ } \\
\text { pier }^{2} \\
\text { (feet) }\end{array}$ & $\begin{array}{l}\text { Contraction } \\
\text { scour depth } \\
\text { (feet) }\end{array}$ & $\begin{array}{c}\text { Abutment } \\
\text { scour } \\
\text { depth } \\
\text { (feet) }\end{array}$ & $\begin{array}{l}\text { Pier } \\
\text { scour } \\
\text { depth } \\
\text { (feet) }\end{array}$ & $\begin{array}{l}\text { Depth of } \\
\text { total scour } \\
\text { (feet) }\end{array}$ & $\begin{array}{c}\text { Elevation of } \\
\text { scour }^{2} \\
\text { (feet) }\end{array}$ & $\begin{array}{c}\text { Remaining } \\
\text { footing/pile } \\
\text { depth } \\
\text { (feet) }\end{array}$ \\
\hline \multicolumn{12}{|c|}{ 500-yr. discharge is 2,260 cubic-feet per second } \\
\hline Left abutment & 0.0 & 1452.4 & 97.66 & 81 & 85.4 & 0.0 & 5.4 & -- & 5.4 & 80.0 & -1 \\
\hline Right abutment & 20.8 & 1452.8 & 98.13 & 81 & 86.1 & 0.0 & 5.0 & -- & 5.0 & 81.1 & 0 \\
\hline
\end{tabular}

1. Measured along the face of the most constricting side of the bridge.

2. Arbitrary datum for this study. 


\section{SELECTED REFERENCES}

Arcement, G.J., Jr., and Schneider, V.R., 1989, Guide for selecting Manning's roughness coefficients for natural channels and flood plains: U.S. Geological Survey Water-Supply Paper 2339, 38 p.

Barnes, H.H., Jr., 1967, Roughness characteristics of natural channels: U.S. Geological Survey Water-Supply Paper 1849, 213 p.

Brown, S.A. and Clyde, E.S., 1989, Design of riprap revetment: Federal Highway Administration Hydraulic Engineering Circular No. 11, Publication FHWA-IP-89-016, 156 p.

Federal Highway Administration, 1983, Runoff estimates for small watersheds and development of sound design: Federal Highway Administration Report FHWA-RD-77-158

Froehlich, D.C., 1989, Local scour at bridge abutments in Ports, M.A., ed., Hydraulic Engineering--Proceedings of the 1989 National Conference on Hydraulic Engineering: New York, American Society of Civil Engineers, p. 13-18.

Hayes, D.C.,1993, Site selection and collection of bridge-scour data in Delaware, Maryland, and Virginia: U.S. Geological Survey WaterResources Investigation Report 93-4017, 23 p.

Interagency Advisory Committee on Water Data, 1982, Guidelines for determining flood flow frequency: U.S. Geological Survey, Bulletin 17B of the Hydrology Subcommittee, 190 p.

Johnson, C.G. and Tasker, G.D.,1974, Progress report on flood magnitude and frequency of Vermont streams: U.S. Geological Survey Open-File Report 74-130, 37 p.

Lagasse, P.F., Schall, J.D., Johnson, F., Richardson, E.V., Richardson, J.R., Chang, F., 1991, Stream Stability at Highway Structures: Federal Highway Administration Hydraulic Engineering Circular No. 20, Publication FHWA-IP-90-014, 195 p.

Laursen, E.M., 1960, Scour at bridge crossings: Journal of the Hydraulics Division, American Society of Civil Engineers, v. 86, no. HY2, p. 39-53.

Potter, W. D., 1957a, Peak rates of runoff in the Adirondack, White Mountains, and Maine woods area, Bureau of Public Roads

Potter, W. D., 1957b, Peak rates of runoff in the New England Hill and Lowland area, Bureau of Public Roads

Richardson, E.V., Harrison, L.J., Richardson, J.R., and Davis, S.R., 1993, Evaluating scour at bridges: Federal Highway Administration Hydraulic Engineering Circular No. 18, Publication FHWA-IP-90-017, 131 p.

Richardson, E.V., Simons, D.B., and Julien, P.Y., 1990, Highways in the river environment: Federal Highway Administration Publication FHWA-HI-90-016.

Ritter, D.F., 1984, Process Geomorphology: W.C. Brown Co., Debuque, Iowa, 603 p.

Shearman, J.O., 1990, User's manual for WSPRO--a computer model for water surface profile computations: Federal Highway Administration Publication FHWA-IP-89-027, 187 p.

Shearman, J.O., Kirby, W.H., Schneider, V.R., and Flippo, H.N., 1986, Bridge waterways analysis model; research report: Federal Highway Administration Publication FHWA-RD-86-108, 112 p.

Talbot, A.N., 1887, The determination of water-way for bridges and culverts.

U.S. Department of Transportation, 1993, Stream stability and scour at highway bridges, Participant Workbook: Federal Highway Administration Publication FHWA HI-91-011.

U.S. Geological Survey, 1966, Delectable Mountain, Vermont 7.5 Minute Series quadrangle map: U.S. Geological Survey Topographic Maps, Photoinspected 1983, Scale 1:24,000. 


\section{APPENDIX A: \\ WSPRO INPUT FILE}




\section{WSPRO INPUT FILE}

$Q$

SK

*

XS

GR

GR

GR

GR

GR

$\mathrm{N}$

SA

XS

*

Q

XS

BR

GR

GR

GR

$\mathrm{N}$

CD

*

XR

GR

GR

*

AS

GR

GR

GR

GR

GR

$\mathrm{N}$

SA

*

HP 1 BRIDG

HP 2 BRIDG

HP 1 APPRO

HP 2 APPRO

\section{*}

HP 1 BRIDG

HP 2 BRIDG

$\mathrm{HP} 1 \mathrm{APPRO}$

HP 2 APPRO

RDWAY
U.S. GEOLOGICAL SURVEY WSPRO INPUT FILE bridO42.wsP CREATED ON 03-OCT-95 FOR BRIDGE BRIDTHO0040042 USING FILE brid042.dCa HYDRAULIC ANALYSIS OF BRID042 SAO

$\begin{array}{lllllllllllllllllllll}6 & 29 & 30 & 552 & 553 & 551 & 5 & 16 & 17 & 13 & 3 & * & 15 & 14 & 23 & 21 & 11 & 12 & 4 & 7 & 3\end{array}$

$1780 \quad 2260$

0.02210 .0221

EXITX -45

$-80.1,105.48$

$-13.3, \quad 95.49$

$-59.4,100.61$

$-51.6, \quad 99.61$

$-33.0, \quad 99.51$

$-4.0, \quad 87.28$

$0.0, \quad 85.36$

$6.3, \quad 84.67$

$12.7, \quad 84.11$

$18.0,83.16$

$21.8, \quad 83.37$

$25.8,84.15$

$34.7, \quad 86.56$

$36.7, \quad 89.67$

$46.7, \quad 93.13$

$85.9, \quad 96.11$

$133.0, \quad 98.27$

$143.9,103.36$

0.055

$-13.3$

0.062

0.060

$72.5, \quad 94.40$
$0.1, \quad 85.37$

$16.5, \quad 85.37$

97.66

$12.7, \quad 85.03$

$0.0, \quad 97.66$

0.055

135.5 * * 558.8

$$
\begin{array}{rl}
9 & 17.42 \\
-78.2, & 103.19
\end{array}
$$

$-64.3,100.12$

$-50.9,101.09$

$-33.4,100.21$

$0.0,99.35$

$21.3, \quad 99.80$

$56.9,100.25$

$100.0,101.67$

$$
55 * 1
$$

$$
-48.5, \quad 106.21
$$

$-31.8, \quad 101.52$

$6.2, \quad 87.03$

$3.9, \quad 87.49$

$13.6, \quad 86.95$

$10.8, \quad 86.75$

$27.7,94.01$

$23.8,92.50$

$86.9,106.85$

0.105 0.075

0.072

$$
-4
$$

$-4.0, \quad 93.73$

$7.3, \quad 86.30$

$0.0, \quad 90.43$

$15.7, \quad 87.00$

$9.3, \quad 86.33$

$32.4,99.50$

$18.8, \quad 90.69$

$44.2,100.11$ 


\section{APPENDIX B: \\ WSPRO OUTPUT FILE}


WSPRO OUTPUT FILE

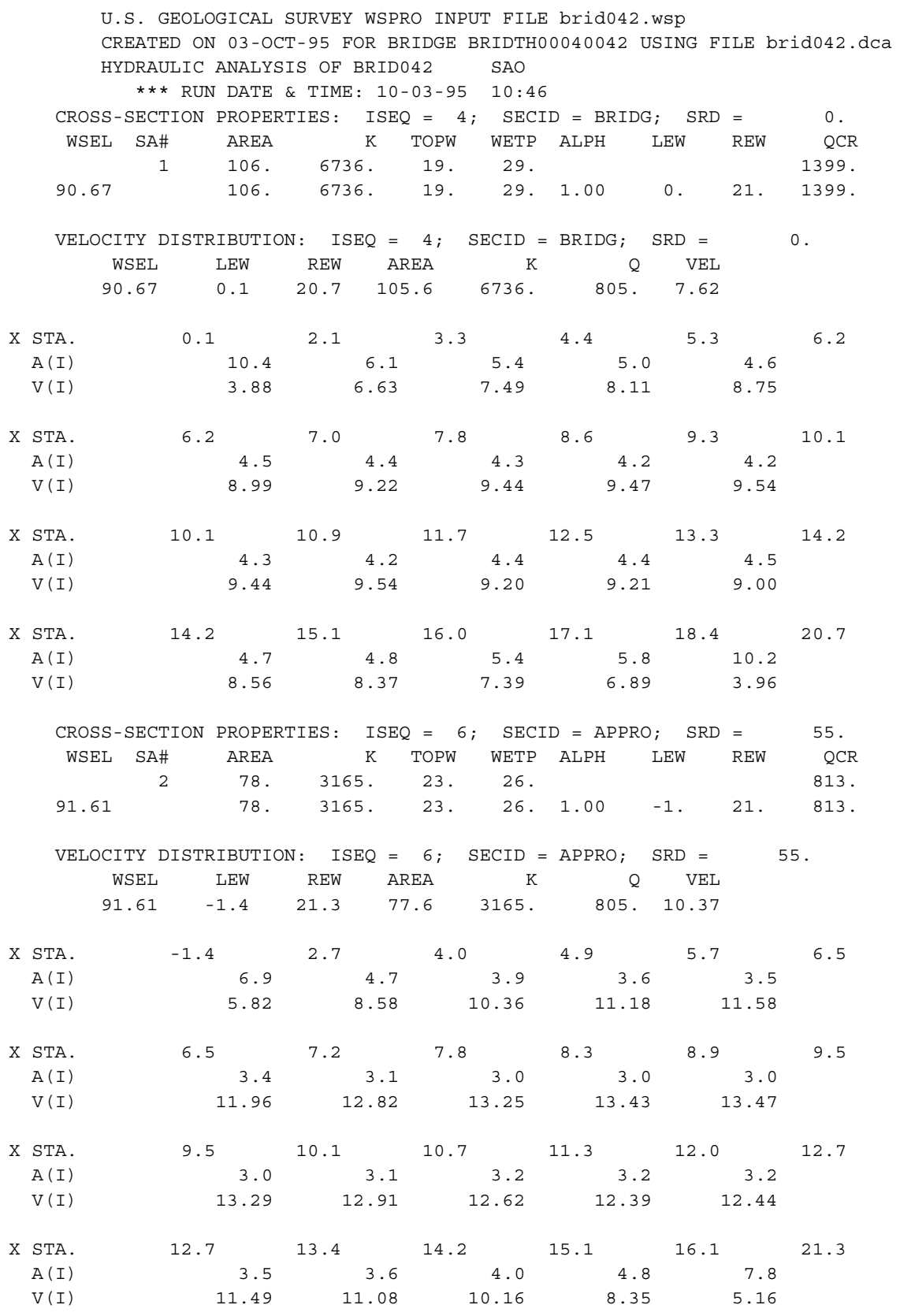


WSPRO OUTPUT FILE (continued)

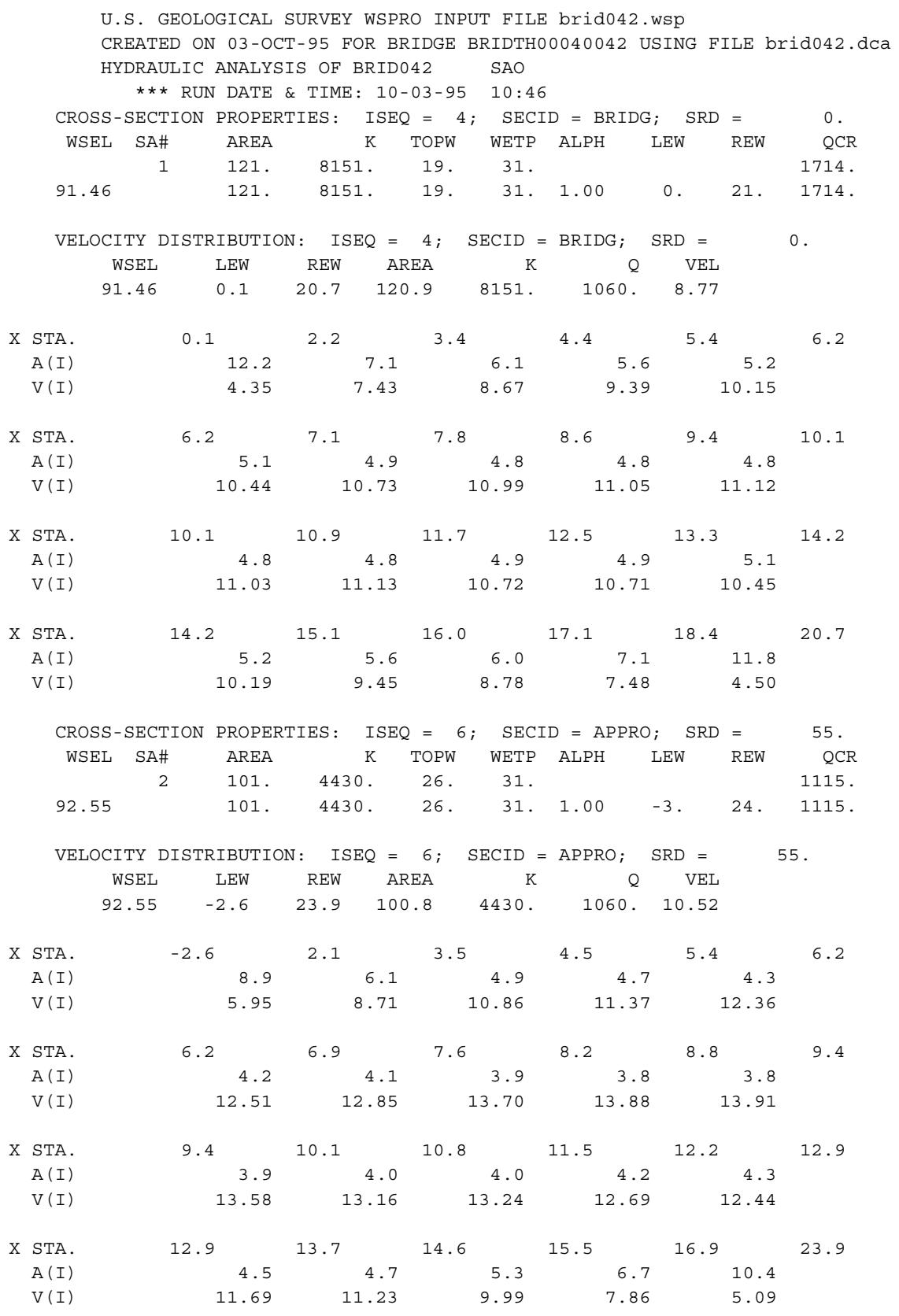


WSPRO OUTPUT FILE (continued)

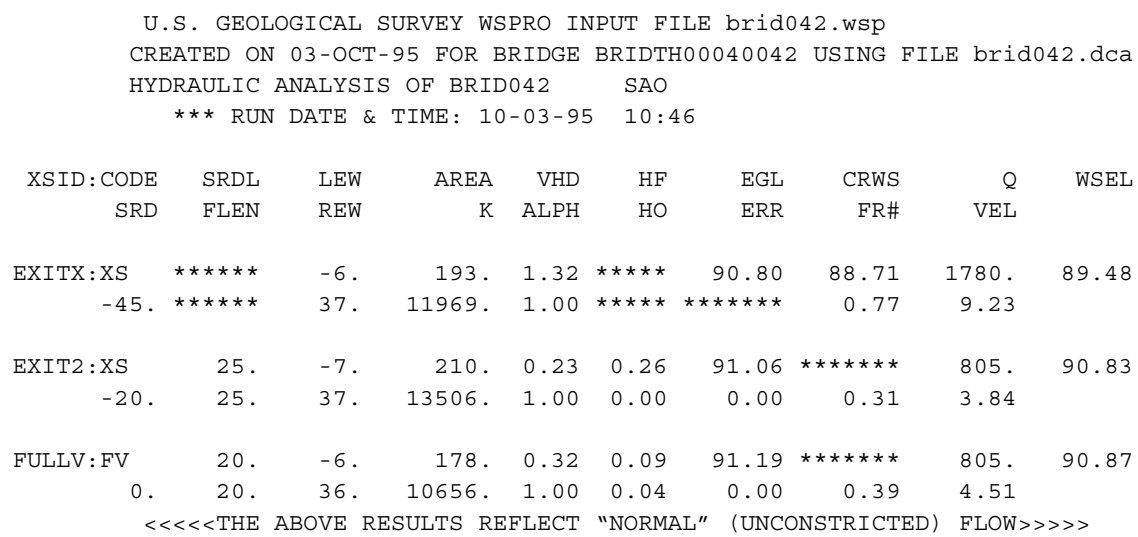

$==125$ FR\# EXCEEDS FNTEST AT SECID "APPRO": TRIALS CONTINUED.

FNTEST, FR\#, WSEL, CRWS $=\begin{array}{llll}0.80 & 0.91 & 91.84 & 91.59\end{array}$

$==110$ WSEL NOT FOUND AT SECID "APPRO": REDUCED DELTAY.

$$
\text { WSLIM1, WSLIM2, DELTAY }=90.37 \quad 106.85 \quad 0.50
$$

$==115$ WSEL NOT FOUND AT SECID "APPRO": USED WSMIN = CRWS.

$$
\text { WSLIM1, WSLIM2, CRWS }=90.37 \quad 106.85 \quad 91.59
$$

$===135$ CONVEYANCE RATIO OUTSIDE OF RECOMMENDED LIMITS

$$
\text { "APPRO" KRATIO }=0.32
$$

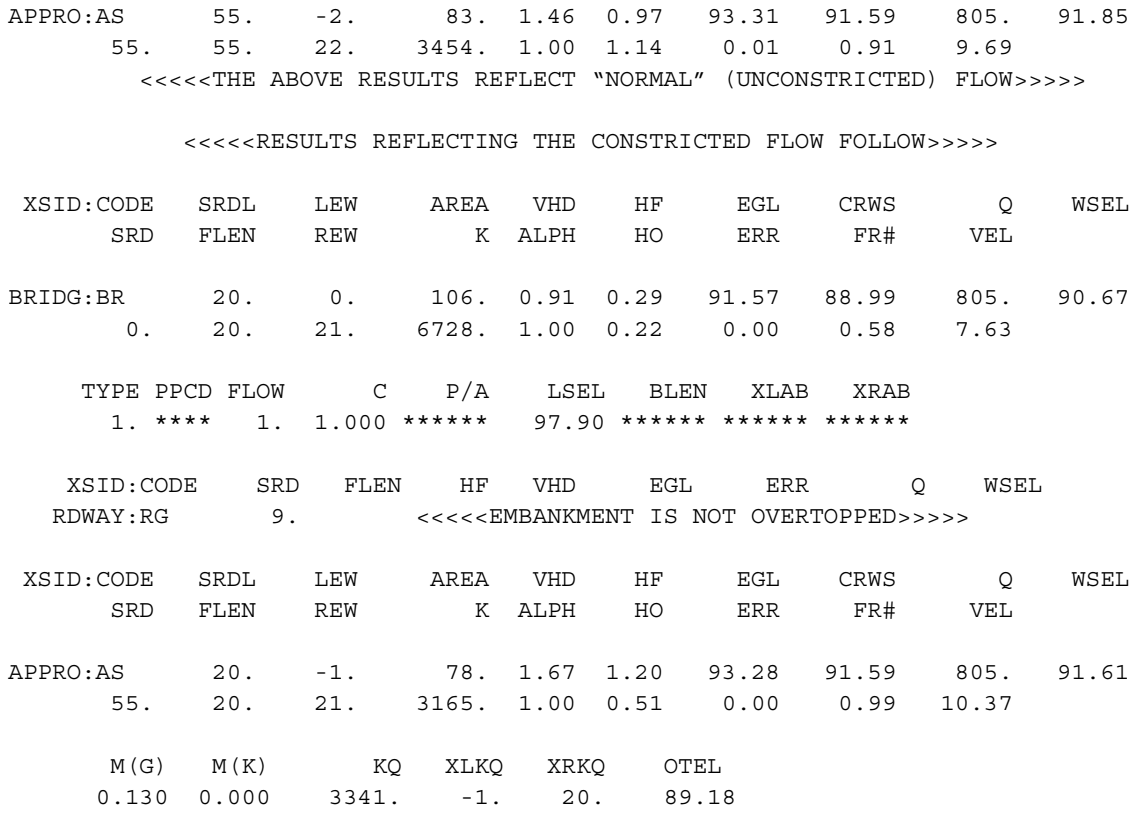


WSPRO OUTPUT FILE (continued)

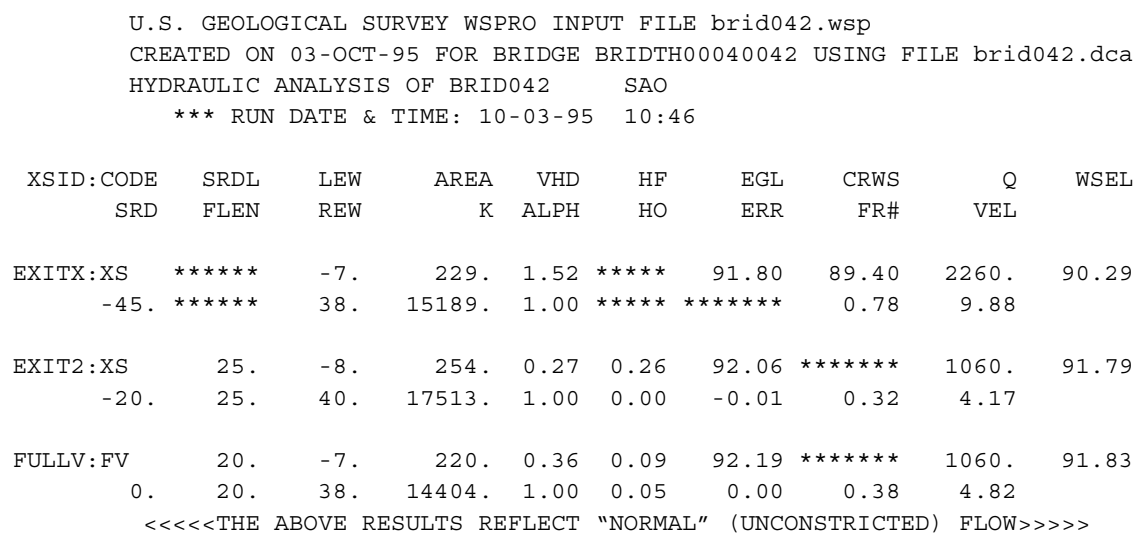

$===125$ FR\# EXCEEDS FNTEST AT SECID "APPRO": TRIALS CONTINUED.

FNTEST, FR\#, WSEL, CRWS $=\begin{array}{llll}0.80 & 0.89 & 92.75 & 92.40\end{array}$

$==110$ WSEL NOT FOUND AT SECID "APPRO": REDUCED DELTAY.

$$
\text { WSLIM1, WSLIM2, DELTAY }=91.33 \quad 106.85 \quad 0.50
$$

$==115$ WSEL NOT FOUND AT SECID "APPRO": USED WSMIN = CRWS.

$$
\text { WSLIM1, WSLIM2, CRWS }=91.33 \quad 106.85 \quad 92.40
$$

$===135$ CONVEYANCE RATIO OUTSIDE OF RECOMMENDED LIMITS

$$
\text { "APPRO" KRATIO }=0.33
$$

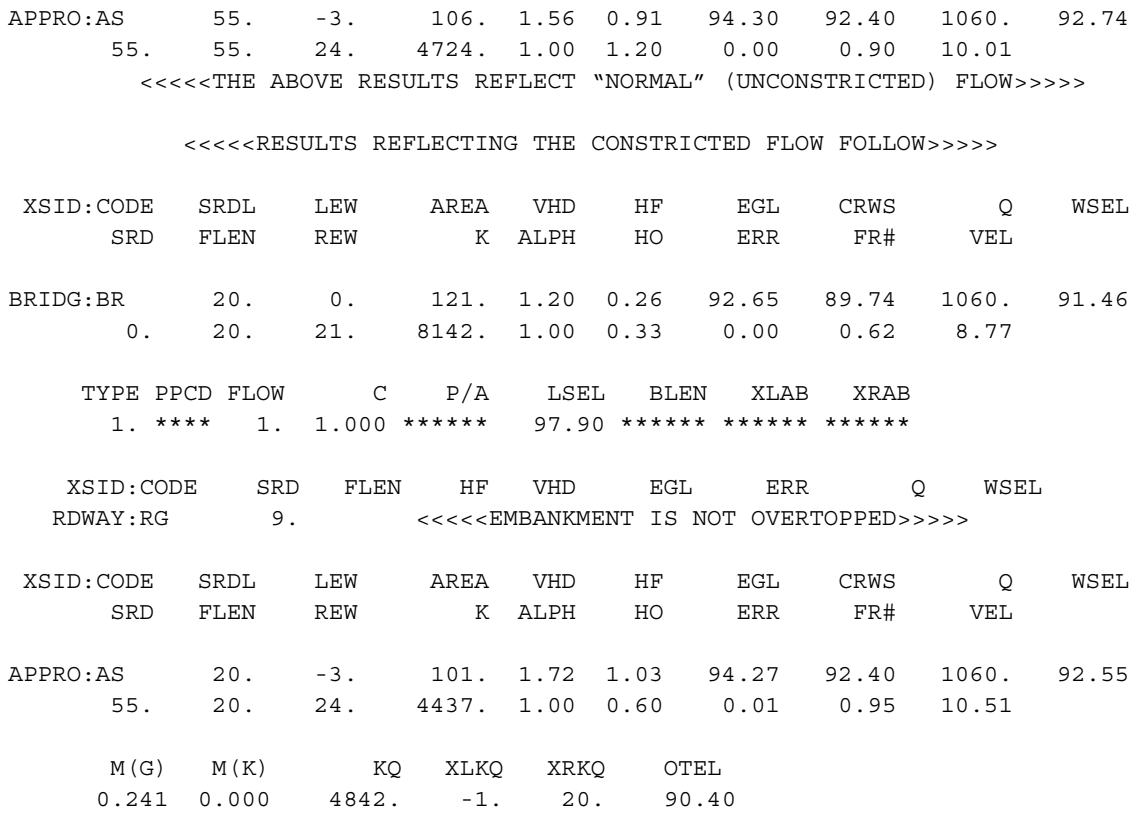

\begin{tabular}{|c|c|c|c|c|c|c|c|c|c|}
\hline \multicolumn{10}{|l|}{ IRST USER D } \\
\hline XSID : CODE & SRD & LEW & REW & $\mathrm{Q}$ & $\mathrm{K}$ & \multicolumn{2}{|c|}{ AREA } & VEL & WSEL \\
\hline EXITX : XS & -45 & -7 & 38. & 2260 . & 15189. & \multicolumn{2}{|c|}{229.} & 9.88 & 90.29 \\
\hline EXIT2:XS & -20 & -8 & 40. & 1060 & 17513 & \multicolumn{2}{|c|}{254 . } & 4.17 & 91.79 \\
\hline FULLV : FV & 0 . & -7 & 38. & 1060. & 14404 . & \multicolumn{2}{|c|}{220 . } & 4.82 & 91.83 \\
\hline BRIDG : BR & 0 . & 0 . & 21. & 1060. & 8142. & \multicolumn{2}{|c|}{121.} & 8.77 & 91.46 \\
\hline RDWAY : RG & \multicolumn{3}{|c|}{ 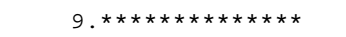 } & \multicolumn{4}{|c|}{$0 . * * * * * * * * * * * * * * * * * *$} & \multicolumn{2}{|c|}{$2.00 * \star \star \star * \star * \star *$} \\
\hline APPRO: AS & 55. & -3 & 24. & 1060. & 4437 . & 10 & & 10.51 & 92.55 \\
\hline \multicolumn{10}{|c|}{ ECOND USER DEFINED TABLE. } \\
\hline XSID : CODE & CRWS & FR\# & YMIN & YMAX & $\mathrm{HF}$ & $\mathrm{HO}$ & VHD & EGL & WSEL \\
\hline EXITX:XS & 89.40 & 0.78 & 83.16 & 105.48 & $3 * * * * * * *$ & $\star \star \star \star \star *$ & 1.52 & 91.80 & 90.29 \\
\hline EXIT2:XS & 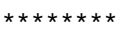 & 0.32 & 84.12 & 106.44 & 0.26 & 0.00 & 0.27 & 92.06 & 91.79 \\
\hline FULLV: FV & $\star \star \star \star * \star * \star *$ & 0.38 & 84.89 & 107.21 & 0.09 & 0.05 & 0.36 & 92.19 & 91.83 \\
\hline BRIDG : BR & 89.74 & 0.62 & 84.76 & 98.13 & 0.26 & 0.33 & 1.20 & 92.65 & 91.46 \\
\hline RDWAY : RG & 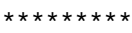 & 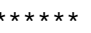 & 99.35 & 103.19 & $* \star * \star *$ & $\star * * *$ & $\star \star \star \star \star * \star *$ & 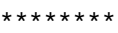 & $\star \star \star \star \star \star \star$ \\
\hline APPRO: AS & 92.40 & 0.95 & 86.30 & 106.85 & 1.03 & 0.60 & 1.72 & 94.27 & 92.55 \\
\hline
\end{tabular}




\section{APPENDIX C:}

\section{BED-MATERIAL PARTICAL-SIZE DISTRIBUTION}




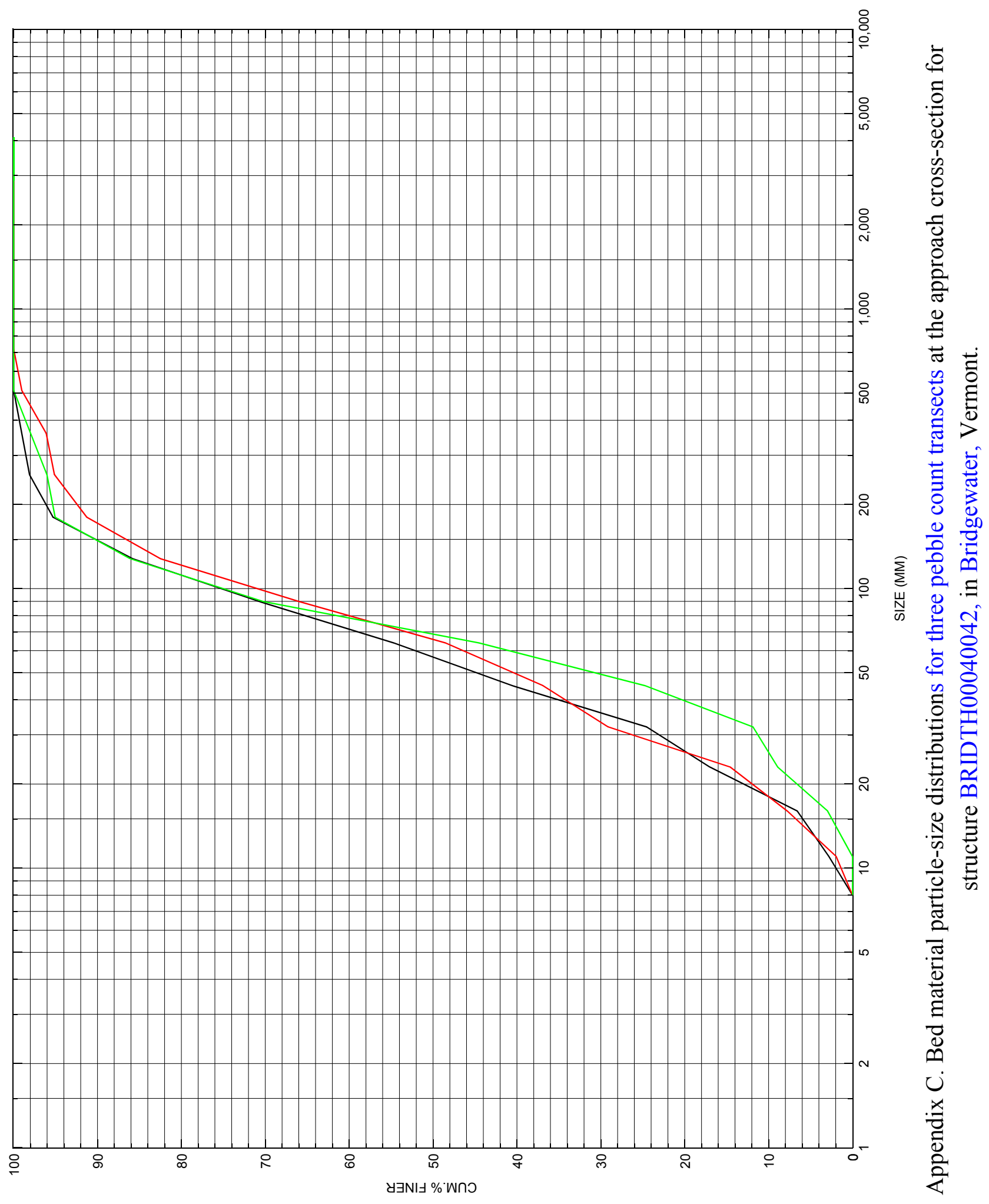




\section{APPENDIX D: \\ HISTORICAL DATA FORM}

